\title{
EDUCATION POLITICS IN ISLAMIC BOARDING SCHOOL AND MADRASA: \\ The Old Order, The New Order, and The Reform Era
}

\author{
Jufri Naldo, Azhari Akmal Tarigan, Faisal Riza \\ Universitas Islam Negeri Sumatera Utara, Indonesia \\ email: aldo_bros@yahoo.co.id, \\ azhariakmaltarigan@uinsu.ac.id,faisalriza@uinsu.ac.id
}

\begin{abstract}
The development of Islamic boarding schools and madrasas in Indonesia cannot be separated from the political education policy of the government that is currently in power. Through a literature study, this study intends to reveal how the form of education politics carried out by the government towards these two institutions. The theoretical debate on education politics during the Old Order begins the explanation of this study. Then, the debate during the New Order is discussed, and the debate related to the Reformation era is discussed after that. This study illustrates that despite the politicization of Islamic boarding schools and madrasas, these indigenous Indonesian educational institutions must be preserved and their development should be considered. Furthermore, Islamic boarding schools and madrasas are important indicators for the progress of the religion and the nation. By looking at the realities of advanced education today, Islamic boarding schools and madrasas are a reflection of the superiority of scientific, intellectual, and cultural achievements. The government as a policymaker should provide full political support so that Islamic boarding schools and madrasas can compete at the world level.

الملخص: لايمكن فصل تطوير المدارس الداخلية الإسلامية والمدارس الدينية في إندونيسيا

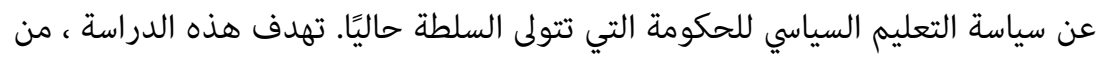

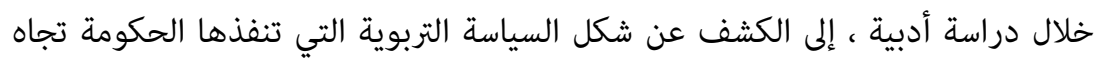

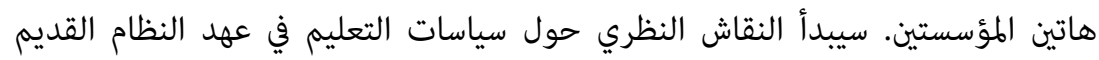


في شرح هذه الدراسة ، ثم يتبعها في عهد النظام الجديد ، وينتهي خلال فترة الإصلاح.

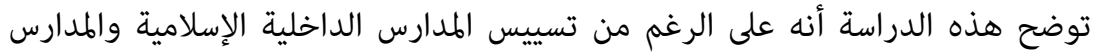

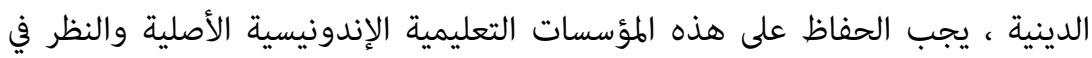

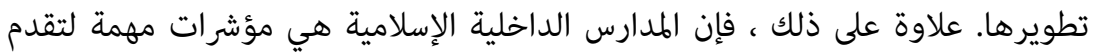

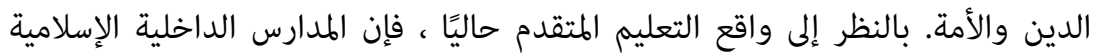

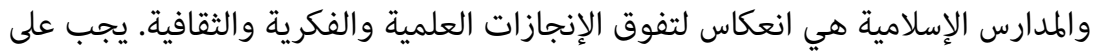

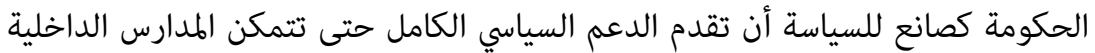
الإسلامية والمدارس الإسلامية من المنافسة على المستوى العالمي.

Abstrak: Perkembangan Pesantren dan madrasah di Indonesia tidak dapat dipisahkan dari kebijakan politik pendidikan pemerintah yang sedang berkuasa. Melalui studi literatur, kajian ini hendak mengungkap bagaimana bentuk politik pendidikan yang dijalankan oleh pemerintah terhadap kedua lembaga tersebut. Perdebatan teoritis politik pendidikan pada masa Orde Lama akan mengawali penjelasan kajian ini, kemudian disusul pada masa Orde Baru, dan diakhiri pada masa Reformasi. Kajian ini memberikan gambaran bahwa sekalipun terjadi politisasi terhadap pesantren dan madrasah, akan tetapi lembaga pendidikan asli Indonesia ini harus tetap dilestarikan dan diperhatikan perkembangannya. Selanjutnya, pesantren dan madrasah merupakan salah satu indikator penting untuk kemajuan agama dan bangsa. Dengan melihat realitas pendidikan yang sudah maju saat ini, pesantren dan madrasah adalah cerminan dari keunggulan capaian keilmuan, intelektual dan kultural. Pemerintah sebagai pemangku kebijakans udah sepatutnya memberikan dukungan penuh secara politik agar pesantren dan madrasah bisa bersaing di tingkat dunia.

Keywords: politics education, goverment, islamic boarding school, madrasah.

\section{INTRODUCTION}

Every time there is a change of government regime in Indonesia, at that time the policy towards education also changes. This kind of 
thing happens because every regime has a different political policy. Islamic boarding schools and Islamic schools are Islamic educational institutions that cannot avoid the policy.

Juridically, the politics of education in Indonesia is outlined in the Education System Law. To date, the are three National Education System Laws have been issued, namely Basic Education and Teaching Law No. 4 of 1950 jo Law No. 12 of 1954 issued during the Old Order, National Education System Law No. 2 of 1989 during the New Order era, and the National Education System Law No. 20 of 2003 in the Reformation era. The Islamic boarding school as a forerunner to the original educational institution in Indonesia only received a juridical recognition in 2003 through the National Education System Law No. 20 of 2003. While madrasa is recognized as a sub-system in the national education system after slowly reducing the lessons of Islamic religious sciences. ${ }^{1}$

Meanw h ile, in the 1945 Constitution (Article 31), every Indonesian citizen has the right to receive a proper education. The consequence of this article is that the government as the policy maker is mandated to implement the National education system. In doing so, the government provides opportunities for the community to get an education, whether managed by the government or by foundations/ the private sector, but still under the coordination of the government.

The p r oblem that arises from the policies issued by the government above is why Islamic boarding schools and madrasas which are part of educational institutions in Indonesia do not fully obtain the constitutional rights contained in this law. Among them are related to budget, infrastructure, human resources, curriculum auton o my, and others. The policy made by the government is a provision that contains principles to direct the ways of acting which are planned and consistent in achieving certain goals. ${ }^{2}$ Dunn said that the policy system is a dialectical process in which the objective and subjective dimensions of policy making cannot be separated from its practice. $^{3}$

1 Ali Anwar, Pembaruan Pendidikan di Islamic Boarding School Lirboyo Kediri (Yogyakarta: Pustaka Pelajar, 2010), 35.

2 Rokim, "Analisis Kebijakan Versi Dunn \& Implementasinya dalam Pendidikan Islam," Pancawahana 14, no. 2 (2019), 61.

3 William N. Dunn, Pengantar Analisis Kebijakan Publik (Yogyakarta: Gajah Mada University Press, 1999), 39. 
As in curriculum policy, for example, there is still a dichotomy in the meaning and implementation between religious education and general education. In article 15 reads "the type of education includes general, vocational, academic, professional, vocational, religious and special education". ${ }^{4}$ From this article, it is clear that there is a dichotomy in education, namely that the type of education is separated at a different pole, namely the existence of religious education that is separate from general education. "Such a dichotomous education system has proven to have failed to produce pious people with Islamic personalities. $^{5}$

Therefore, this article intends to examine how the government has implemented policies towards Islamic boarding schools and madrassas during the Old Order, the New Order, and the Reform era. In each of these regime changes, the education politics run by the government has benefited Islamic boarding schools and madrasas. Because in Indonesia there are many and various educational institutions. Such as Islamic boarding schools, madrasas, and public schools. These three institutions share a role in providing knowledge and empowering society. People are given the freedom to choose existing educational institutions. For those who want to master general education they can choose the general education pathway, those who want to deepen and master religious education can choose Islamic boarding schools, and those who want to understand and understand both (religion and general) can take the madrasa route.

However, it needs to be emphasized that Islamic boarding schools are institutions that can be said to be a manifestation of a natural process of developing the national education system. From a historical perspective, Islamic boarding schools are not only identical with Islamic meaning but also contain indigenous meaning. This is because Islamic boarding schools have existed since the time of Hindu-Buddhist rule. So that Islam just continues and Islamizes existing educational institutions. Of course, this does not mean diminishing the role of Islam in pioneering education in Indonesia. ${ }^{6}$

4 Undang-undang Republik Indonesia, "Nomor 20 Tahun 2003 Tentang Sistem Pendidikan Nasional" (2003).

5 Hasbullah Hadi et al., "Kebijakan Pendidikan Nasional Terhadap Pendidikan Islam dan Pendidikan Sekuler," Miqot XL, no. 2 (2016), 391.

6 Nurcholish Madjid, Bilik-bilik Islamic Boarding School: Sebuah Potret Perjalanan (Jakarta: Dian Rakyat, 1997), 3. 
Madrasas are not known since when as a term -a term- for a type of Islamic education in Indonesia. Even so, madrasas as an Islamic education system that has classes and teaches religious and general science has been seen since the early 20th century. Although some of the educational institutions use the term school (school) but are viewed from an integrated education system, such education can be categorized in the form of madrasas. ${ }^{7}$

\section{ISLAMIC BOARDING SCHOOL AND MADRASA IN THE POLITICS OF EDUCATION IN THE OLD ORDERR}

After Indonesia's independence, the education system has the opportunity to develop more broadly, openly, and democratically. The people welcomed a new era of education that had not been felt before due to colonial political pressures. Because before independence, the Dutch government categorized Islamic education institutions in Indonesia as illegal schools. ${ }^{8}$ In fact, to limit and suppress the development of these Islamic educational institutions, the Netherlands in 1933 issued a regulation known as the wild schoolenordonantie. ${ }^{9}$ As a result, Islamic education has difficulty developing and tends to be closed to accepting thoughts that come from outside the Islamic tradition and Islamic boarding schools. ${ }^{10}$ Even though Islamic education got the opportunity to develop after the Dutch colonialism, however, this opportunity became a blowback for the Islamic boarding school, because madrasas were in great demand by the public. ${ }^{11}$ Coupled with the birth of the proclamation, which gave a new style to religious education, the Islamic Boarding Schools did not do much of their duties anymore, while madrasas developed very rapidly.

7 Maksum, Madrash; Sejarah dan Perkembangannya (Jakarta: Logos Wacana Ilmu, 1999), 97.

${ }_{8}$ Karel A. Steenbrink, Islamic Boarding School, Madrasah, Sekolah: Pendidikan Islam dalam Kurun Modern (Jakarta: LP3S, 1994), 7.

9 H.A.R. Tilaar, Paradigma Baru Pendidikan Nasional (Bandung: Rineka Cipta, 2004), 169.

${ }^{10}$ Moh. Miftachul Choiri and Aries Fitriani, "Problematika Pendidikan Islam Sebagai Sub Sistem Pendidikan Nasional di Era Global," Al-Tahrir: Jurnal Pemikiran Islam 11, no. 2 (2011), 305.

${ }^{11}$ Mujamil Qomar, Islamic Boarding School: Dari Transformasi Metodologi Menuju Demokratisasi Institusi (Jakarta: Erlangga, 1996), 13-14. 
Madrasa in the Old Order era continued to grow because the number of these institutions increased in the Islamic boarding school institutions. The presence of madrasas does not mean to override traditional recitation, but rather to complete it. Madrasas and traditional recitation using the method of sorogan and bandongan always go hand in hand. ${ }^{12}$ After independence, many Islamic boarding schools adapted to the demands, among others by holding formal education mainly in the form of madrasas, while also continuing the wetonan and sorogan system. ${ }^{13}$

Therefore, Islamic education received more serious attention from the government after Indonesia's independence, especially after the founding of the Department of Religion. The Central National Committee for Workers (BPKNIP) in December 1945 recommended that madrasas education continue. The agency also urged the government to assist madrasas. The Ministry of Religion immediately established a special section tasked with arranging Islamic religious and Christian education lessons and education, overseeing the appointment of religious teachers, and overseeing religious education. ${ }^{14}$ The Department of Religion also recommends that a traditional Islamic boarding school is developed into a madrasas, arranged classically, using a fixed curriculum, and incorporating general subjects, so that students at the madrasas receive the same general education as students in public schools..$^{15}$

The seriousness of the government is realized by placing religion as a foundation in building the nation and state. This can be seen in the Preamble to the third and fourth paragraphs of the 1945 Constitution, that Indonesia's independence was due to the blessing of Allah's Grace and the first principle of the Five Principles of God as the basis of the state. Then in article 29 paragraph (1) and (2) of the 1945 Constitution it is stated that the state is based on the Almighty God and guarantees the independence of each population to embrace

${ }^{12}$ Qomar, 94.

${ }_{13}$ Marwan Saridjo, Sejarah Pondok Islamic Boarding School di Indonesia (Jakarta: Dharma Bhakti, 1982), 59.

${ }^{14}$ Samsul Munir Amin, Sejarah Peradaban Islam (Jakarta: Amzah, 2010), 420.

${ }^{15}$ Badri Yatim, Sejarah Peradaban Islam: Dirasah Islamiyah II (Jakarta: Rajawali Pers, 2010), 311. 
their respective religions and to worship according to their religion and beliefs. ${ }^{16}$

Related to education, the 1945 Constitution of Chapter XIII article 31 paragraph (1) states that each citizen has the right to receive teaching, and paragraph (2) stipulates that the government strives for and operates a national education system regulated by law. ${ }^{17}$

Departing from several articles in the 1945 Constitution above, it can be seen that Indonesia initially did not choose a dualistic education system as a colonial strategy, but instead made various educational systems that had developed into several sub-systems that were part of the national education system without dichotomizing an education system. Besides, the Indonesian people are also determined to integrate general education and religion, as evidence of gratitude for the independence that has been achieved. ${ }^{18}$

During this period, Islamic education was still based on the previous education system, namely the Islamic boarding school and madrasas. The existence of the Islamic boarding school and madrasa even gained recognition from BPKNIP as the MPR Workers' Body at that time. This can be seen in the Main Education and Teaching Businesses formulated by BPKNIP. The formula which consists of 10 articles in article 5 states that Islamic boarding schools and madrassas are in principle one of the tools and sources of education for people who are deeply rooted in Indonesia. Therefore, it is only natural to receive attention and assistance from the government. ${ }^{19}$

Based on this article, it can be understood that Islamic boarding schools and madrasas not only receive recognition but also support in the form of guidance and guidance. The authority to guide Islamic boarding schools and madrasa is then left to the Department of Religion. The department, which was formed on January 3, 1946, has the task of, among others, managing religious education issues in madrasas and Islamic boarding schools and managing religious education in public schools.

${ }^{16}$ Anwar, Pembaruan Pendidikan di Islamic Boarding School Lirboyo Kediri, 36.

${ }^{17}$ C.S.T. Kansil, Mendalami P4, UUD 1945, dan GBHN (Jakarta: PN Balai Pustaka, 1985), 428-435.

${ }^{18}$ Anwar, Pembaruan Pendidikan di Islamic Boarding School Lirboyo Kediri, 37.

${ }^{19}$ Djamil Latief, Himpunan Peraturan-peraturan Tentang Pendidikan Agama (Jakarta: Ditbinpendais Depag RI, 1983), 14. 
Besides, especially in the Wilopo cabinet, the Department of Religion's work was added, namely implementing teacher training for teaching public knowledge in religious schools. The task was then realized by establishing several special schools, namely; (1) Religion Teacher Education (PGA) for six years to become a religion teacher in the People's School (SR). (2) School of Teachers and Religious Judges (SGHA), to become religious teachers in Junior High Schools. The education that was undertaken for two years after the PGA consisted of 4 parts/majors, namely A (Literature), part B (Definitive Science), part C (Religious Sciences), and part D (Religious Law). (3) State Islamic Higher Education Institutions (PTAIN) to become teaching staff in Senior High Schools, and (4) Religious Teacher Education (PGA) to become general teachers in low-level religious schools (SR). Meanwhile, to become general teaching staff in religious schools at the secondary level, a collaboration with the Ministry of Teaching and Culture (PP and K) is held. ${ }^{20}$

Furthermore, one of the documents stated that the duties of the education department within the Ministry of Religion include; (1) Give religious studies in Particular State Schools. (2) Providing general knowledge in madrasas, and (3) Providing Religious Teacher Education (PGA) and State Islamic Judge Education (PHIN). Of course, at this time, the administration of Madrasas received help and guidance from the Department of Religion. ${ }^{21}$

With the tasks as described above, the Department of Religion can be said to be a representation of Muslims in the fight for the implementation of Islamic education more broadly in Indonesia. Concerning the development of madrasas, the Department of Religion has become a mainstay that can politically elevate the position of madrasas so that it receives constant attention among policymakers. In addition to continuing efforts that have been initiated by several figures such as Achmad Dahlan, Hasyim Asy' ari, and Mahmud Yunus -the Ministry of Religion has sharply developed programs to expand and improve the quality of madrasa.

Given the increasing task of handling the problem of Islamic education, the education department at the Ministry of Religion

${ }^{20}$ SKI Fakultas Adab UIN Yogyakarta, Sejarah Peradaban Islam di Indonesia (Yogyakarta: Pustaka, 2006), 156-57.

${ }^{21}$ Latief, Himpunan Peraturan-peraturan Tentang Pendidikan Agama, 56. 
was developed into the Office of Religious Education in 1950. This body has a very important and strategic role within the Department of Religion, given the task of developing education as a vast and challenging arable land. Almost all changes and development of madrasa/religious education in the Old Order era depends on the policies issued by this department. ${ }^{22}$

To improve madrasa following BPKNIP's advice, the Ministry of Religion issued Minister of Religion Regulation No. 1 of 1946, and then perfected by Regulation of the Minister of Religion No. 7 of 1952, which regulates the level of education in madrasas. According to this regulation, the level of education at madrasas consists of; (1) low madrasas (now called Madrasah Ibtidaiyah), madrasas that contain Islamic education and science as the subject of their teaching, have six years of education. (2) Advanced Level madrasas (now called Madrasah Tsanawiyah), is a madrasas that accepts graduates of Low madrasas or equivalent, and provides education in Islamic religious knowledge as the subject of their teaching, three years of education, and (3) upper advanced madrasas (now called Madrasah Aliyah), is a madrasas that accepts graduates of the first advanced madrasas or its equivalent, and provides education in Islamic religious knowledge as the subject of its teaching, three years-long studies.

Efforts to improve the quality of madrasas are also carried out by improving the status of madrasas that are managed by the community, both private and organizational, from the private sector to the state. The negated madrasas began at the elementary level which was named the Madrasah Ibtidaiyah Negeri (MIN), the first advanced level was named the Madrasah Tsanawiyah of the State Islamic Religion (MTsAIN), and the upper level was given the name Madrasah Aliyah Negeri Islam Religion (MAAIN). ${ }^{23}$ Besides, the Islamic boarding school also accepted the change in the stat us of the madrasa to become a state madrasa because it was considered very profitable in terms of the Islamic boarding school's finances. The Islamic boarding school no longer relies too much on income from students or donations from the community to pay teachers. ${ }^{24}$

\footnotetext{
${ }^{22}$ Maksum, Madrash: Sejarah dan Perkembangannya, 125.

${ }^{23}$ Maksum, 153.

${ }^{24}$ Madjid, Bilik-bilik Islamic Boarding School: Sebuah Potret Perjalanan, 82.
} 
Furthermore, driven by the desire to modernize the world of Islamic boarding school and madrasa, around 1958, the Department of Religion held a revolutionary renewal in the field of education in madrasas. This was realized by establishing a Compulsory Education Madrasas (MWB) with an eight-year study period. The aim is to prepare the quality of students to be able to live independently and earn a living, especially in the economic, industrial, and transmigration fields. To achieve that goal, the curriculum is prepared by considering the harmony of three child developments, namely brain development or mind (cognitive), heart development or feelings (affective), and the development of dexterity/skills (psychomotor). ${ }^{25}$ Whereas the subject matter provided at this Madrasas consists of religious subjects, general knowledge, and crafts/skills, with a ratio of $25 \%$ for religious studies and $75 \%$ for general knowledge and skills. But this program cannot run well, due to the lack of infrastructure and the availability of teaching staff, as well as the lack of response from the community and related parties.

The law on the education system that was first owned by Indonesia turned out to apply

madrasas in a discriminatory manner. In the Basic Education and Teaching Law No. 4 of 1950 it was stated that studying in madrasas which had been recognized by the Minister of Religion was considered to have fulfilled the learning obligation, even though the same provisions did not apply to public schools. Even so, these provisions are considered as recognition of the existence of madrasas in the national education system.

As a follow up to the Act, the Department of Religion issued a policy that madrasas that are recognized and meet the requirements to carry out learning obligations must be registered with the Department of Religion. As one of the requirements for registering an institution, the madrasa concerned must teach religious lessons as a subject at least six hours a week regularly in addition to general lessons. ${ }^{26}$

The development of elementary level madrasas (Ibtidaiyah) quantitatively in 1957 to 1960 s recorded 13,057 with a total of 1,927,777 students. The number of first-level madrasas (Tsanawiyah)

${ }^{25}$ Mulyanto Sumardi, Sejarah Singkat Pendidikan Islam di Indonesia 1945-1975 (Jakarta: Dharma Bhakti, 1978), 49.

${ }^{26}$ Sumardi, 40. 
reached 776 with 87,932 students. The number of madrasas at the top (Aliyah) is around 16 with a total number of 1,881 students. Thus, the total number of madrasas has reached 13,849 with a total number of 2,017,590 students. ${ }^{27}$ However, the existence of madrasas has not become part of the national education system which is identical to the institutions managed by the Ministry of National Education. Madrasas are still considered second-class educational institutions.

To motivate madrasas to improve the quality of their learning, the government also provides financial assistance. In the 1960s, according to van Bruinessen's findings, the Department of Religion provided a local madrasas subsidy of Rp. 10 per student, but for madrasas affiliated with national scale organizations, the subsidy was increased to no less than Rp. 30, -each student. This policy has an impact on increasing the number of madrasas. This assistance is based on the Republic of Indonesia's Minister of Religion Regulation No. 2 of 1960.

To get this assistance, religious education institutions must meet certain conditions. ${ }^{28}$ Among other things, besides teaching Islam, it also teaches general knowledge which is the same level as general lessons for low schools, teaches Indonesian language, exact science, earth science, general history, life science, and English for Tsanawiyah Madrasas, and teaches algebra- graphs, geometry, geography, state administration, cultural history, Indonesian literat ure, and economics.

Even so, it turns out that the government's attention to madrasas is still very small. This can be seen from Law No. 4 of 1950 article 3 which states that the purpose of education is "to form capable human beings and citizens who are democratic and responsible for the welfare of society and the motherland." From this formulation, there is no reflection on the serious efforts to foster spiritual and religious mentality through the educational process. That is why Article 20 paragraph 1 it is stated that religious education in schools is not a compulsory subject and depends on the consent of the students' parents. In his explanation, it was even stated that the subject of religious education was not a determining factor in the promotion of the class of students.

${ }^{27}$ Maksum, Madrash; Sejarah dan Perkembangannya, 126.

${ }^{28}$ Martin van Bruinessen, NU: Tradisi, Relasi-relasi Kuasa, Pencarian Wacana Baru, Terj. Farid Wajidi (Yogyakarta: LKIS, 1994), 80. 
Beyond that law, government policies especially those concerning religious education are not static. Several MPRS/ MPR decrees, Government Regulations, Government Decrees, and Ministerial Decrees were issued. Some of the decisions paid little attention to religious education and its institutions. On December 3, 1960, for example, MPRS Decree No. came out. II /MPRS/1960 concerning "Outlines of the National Development Plan, First Stages in 1961-1969." Concerning national education, this provision, among others, states that religious education is a subject in schools ranging from public schools to state universities, with the understanding that students have the right not to participate if the guardian of students/ adult students objects. ${ }^{29}$

This provision does not change the stat us of religious education as a minor/elective subject but has expanded its reach to the university level. Changes like this certainly have not meant much, especially in their implementation when faced with the political situation of NASAKOM which gave a direct role for the Indonesian Communist Party (PKI) in government. However, concerning madrasas, this provision has given attention -although not very meaningful- by recommending that madrasas should stand alone as autonomous bodies under the supervision of the Ministry of Religion and not under the supervision of the Ministry of Education and Culture. "With this recommendation, madrasas remain outside the national education system, but the concrete proposals in this stipulation are steps to uphold madrasas within the framework of national education. ${ }^{30}$

\section{ISLAMIC BOARDING SCHOOL AND MADRASA IN THE POLITICS OF EDUCATION DURING THE NEW ORDER}

During the New Order era, the government increasingly showed its concern for Islamic education. This concern is evident from the 1966 MPRS general session which succeeded in establishing MPRS TAP No. XXVII/MPRS/1996 which discusses religion, education, and culture. Article 1 of the decree explains: "Establish religious

${ }^{29}$ Tadjab, "Posisi Pendidikan Islam dalam Sistem Pendidikan Nasional" (Fakultas Pasca Sarjana IAIN Sunan Kalijaga, 1987), 95.

${ }^{30}$ Maksum, Madrash; Sejarah dan Perkembangannya, 130-131. 
education as a subject in schools ranging from elementary schools to state universities". 31

In the early days of the New Order government, policies in some respects regarding madrasas were to continue and strengthen Old Order policies. At this stage, madrasas have not been seen as part of the national education system, but are an autonomous educational institution under the supervision of the Minister of Religion. This is because the madrasas education system is more dominated by religious content, uses a curriculum that is not standardized, has a non-uniform structure, and imposes management that is less able to be controlled by the government. ${ }^{32}$

Besides, according to the New Order government, the madrasas compulsory education program runs less in line with expectations so that the Department of Religion continues to organize madrasa education curricula that are in line with national education demands. As an effect of MPRS Decree No. XXVII/1966, in 1967 the Minister of Religion issued a policy to establish several madrasas at all levels from the Ibtidaiyah to Aliyah levels. Through this effort as many as 123 Ibtidaiyah Madrasas have been nationalized, thereby increasing the total number of Madrasah Ibtidaiyah Negeri (MIN) to 358. At the same time, around 182 Madrasah Tsanawiyah Negeri and 42 Madrasah Aliyah Negeri Islam have been established. By giving this country status, management responsibility becomes a burden on the government, and control over madrasas becomes more effective. ${ }^{33}$

From the end of the 70s until the end of the 80s, the New Order government began to think about the possibility of integrating madrasas into the National Education System. Efforts towards this direction are not simple because constitutionally national education is still regulated by Law No. 4 of 1950 jo No. 12 of 1954 which ignored madrasa education. What the government can do at this stage is to strengthen the structure of madrasas -both at the level and curriculum- so that graduates receive the same recognition as graduates of public schools and can continue to higher levels of education in schools managed by the Ministry of Education and Culture. For this purpose, a policy was issued in the form of a Joint

\footnotetext{
${ }^{31}$ Maksum, 137.

${ }^{32}$ Maksum, 132.

${ }^{33}$ Maksum, 141.
} 
Decree (SKB) of the Three Ministers in 1975 concerning improving the quality of education in madrasas. ${ }^{34}$

The essence of the Joint Decree is an effort to improve the quality of madrasas, in the decree stated; ${ }^{35}$ (1) madrasa diplomas can have the same grades as public school diplomas of the same level. (2) madrasa graduates can continue to public schools one level above. (3) madrasa students can transfer to public schools of the same level (Three Ministerial Decree 1975, Chapter II, Article 2). The implementation of the Three Ministerial Decree means that the existence of Madrasas as Islamic education institutions is stronger and stronger, general knowledge in Madrasas is increasing, physical facilities and equipment are more refined, and there is a civil effect on Madrasas diplomas.

The Three Ministerial Decree can be considered a milestone in the madrasa modernization. The decree can be called the starting point for the modern implementation of madrasas. Also, the Three Ministerial Decree can be seen as a concrete acknowledgment of the existence of madrasas as well as a strategic step towards the stages of integration of madrasas into the complete national education system. ${ }^{36}$ By following the pattern of administering madrasas as outlined in the Joint Decree, madrasas diplomas are recognized not only by the Ministry of Religion, but also by the Ministry of Education and Culture, and other departments. This can be seen as a positive side that benefits the madrasas. ${ }^{37}$

On the other hand, the New Order government policy as outlined in the Three Ministerial Decree was mostly disputed by most Muslims, especially scholars, because the Three Ministerial Decree was considered to make madrasas students very responsible, not well understanding religious knowledge, also general, so that it would result in scarcity of scholars. To find a solution, the Department of Religion in 1987, during the period of Minister Munawir Sjadzali, established the Madrasah Aliyah Special Program. ${ }^{38}$ This madrasa is

${ }^{34}$ Maksum, 142.

${ }^{35}$ Haidar Putra Daulay, Pendidikan Islam dalam Sistem Pendidikan Nasional Indonesia (Jakarta: Kencana Prenada Media Group, 2004), 152.

${ }^{36}$ Maksum, Madrash; Sejarah dan Perkembangannya, 151.

${ }^{37}$ Maksum, 155.

${ }^{38}$ Abdurahman Saleh, Penyelenggaraan Madrasah: Peraturan Perundangan (Jakarta: Dharma Bhakti, 1984), 19. 
expected to be an institution for printing prospective scholars who understand religion well and also general knowledge, especially Arabic and English. But unfortunately, this MAPK/MAK does not have a legal umbrella, because madrasas which are recognized based on the Three Ministers Decree are 70\% general lessons and 30\% religious lessons. This madrasa is also not yet clarified its position in Law on National Education System No. 2 of 1989. MAPK/MAK, ${ }^{39}$ only got a place in Law on National Education System No. 20 of 2003.

The opening of MAPK is an effort to return madrasas to their original destination with some improvements. MAPK is also intended as a major supplier of students in Islamic tertiary education. However, the number of MAPKs is very limited and is not balanced with a large number of Islamic tertiary institutions, so that the purpose of establishing MAPK is less than the maximum. The condition of madrasas which is seen by some people as having shifted to science has been responded to by establishing madrasah diniyah or preserving Islamic boarding schools as places of religious education. ${ }^{40}$

Entering the 90s, the New Order government policy on madrasas was aimed at building a fully integrated national education system. With one complete system, it is intended that national education not only depends on school path education but also utilizing off-school pathways. To realize this goal, the New Order government took concrete steps in the form of drafting Law No. 2 of 1989 concerning the National Education System and simultaneously replace Law No. 4 of 1950 jo. No. 12 of 1954. In this context, a definitive affirmation of madrasa is given through decisions that are more operational and are included in the school education category without losing its religious character. Through this effort, it can be said that madrasas develops in an integrated manner in the national education system. ${ }^{41}$

These developments have quite fundamental implications for the existence of madrasas. madrasas which were originally seen as religious education institutions can now claim to be public schools

${ }^{39}$ In the National Education System Law No. 2 of 1989 the definition of religious education has been explained in article 11 paragraph (6) and Article 15 paragraph (2) religious education was included as part of secondary education, but the form of religious education was not listed in the Act and its explanation.

${ }^{40}$ Saleh, Penyelenggaraan Madrasah: Peraturan Perundangan, 20.

${ }^{41}$ Saleh, 128. 
plus. Therefore, madrasas get an extra heavy burden, because, in addition to having to provide a full-level public school curriculum, he must also provide essential Islamic material that has been taught. ${ }^{42}$ The weight of the burden borne by the madrasa is still coupled with the low quality of learning resources. However, these efforts do not necessarily position madrasa education substantially parallel to General Education. ${ }^{43}$

\section{ISLAMIC BOARDING SCHOOL AND MADRASA IN THE POLITICS OF EDUCATION DURING THE REFORMATION}

Before the reformation period began, when the government was still implementing the 1994 curriculum, religious education was placed at all levels of education, becoming compulsory subjects from elementary to tertiary education. From the perspective of religious education, the 1994 curriculum was only an improvement and changes that did not affect the number of hours of study and the character of students' religious education, as in previous years. Until the fall of the New Order in 1998, education in Indonesia was still using the 1989 Education Law and the 1994 curriculum. The collapse of the New Order gave rise to the idea of reform, one of which was to change and renewal in the field of education, as was the theme of criticism of observers' education.

During the reform period, there was a change from a centralized to a decentralized system of government. This is indicated by RI Law No. 22 of 1999 concerning Regional Government. Article 7 paragraph (1) RI Law No. 22 of 1999 states that religion is a matter that is not held by local governments. On the other hand, education, according to article 11 paragraph (2) RI Law No. 22 of 1999 is a compulsory matter which is the authority of the regional government. Madrasa, according to the National Education System Law No. 2 of 1989 is defined as a public school that is characterized by Islam, can be debated, whether it is part of religion or education. ${ }^{44}$

${ }^{42}$ Azyumardi Azra, Paradigma Baru Pendidikan Nasional: Rekonstruksi dan Demokratisasi (Jakarta: Kompas, 2002), 71.

43 Azra, 48.

44 Azra, 49. 
The contentious article turns out to be found the solution that educational institutions included as part of religion are Islamic boarding school and Madrasah Diniyah, while madrasas as public schools characterized by Islam are included as part of education. Therefore, madrasa should be handed over to local government management, so that various unfair policies between madrasas educational institutions and schools can be minimized. Unlike the reality that happened to this day, where madrasas are still held by the Ministry of Religion. ${ }^{45}$

In fact, during the administration of President Abdurrahman Wahid, the Islamic boarding school had received several facilities. Through the SKB of Two Ministers Number 1/U/KB/ 2000 and MA/86/2000 Number of students in Salafiyah Islamic boarding school aged 7-15 years who attended Diniyah Awaliyah (basic level) and Diniyah Wustho (first advanced level), who did not currently study at SD/MI and SLTP/MTs or not both of them graduating, can be recognized as having the same ability and equal opportunity to continue learning to a higher level of education, if the Islamic boarding school adds several general subjects of at least 3 subjects, namely Indonesian Language, Mathematics and Natural Sciences, the STTB or Diploma issued by the Islamic boarding school organizing this program is recognized by the government.

However, not all salafiyah Islamic boarding school follow the Two Ministerial Decree above, some of them choose to keep their tradition. This attitude of not following could be due to the ignorance of the Islamic boarding school itself, or it could also be due to their concern about the loss of the Salaf identity that had been maintained so far due to the inclusion of government intervention in the Islamic boarding school curriculum.

Thus, the Islamic boarding school and Madrasah Diniyah as a source of education and community intelligence, which had been entrenched since before independence, had only gained juridical recognition in this reform era. The confession is very clearly stated in Law No. 20 of 2003 concerning the National Education System. In this law, the presence of religious education is recognized as one type of education in addition to other education. ${ }^{46}$

\footnotetext{
${ }^{45}$ Azra, 49-50.

${ }^{46}$ Azra, 53.
} 
Furthermore, the following is the position of religious education in the 2003 National Education System Law Article 1 paragraph (1) which reads; "A conscious and planned effort to create an atmosphere of learning and learning process so that students actively develop their potential to have spiritual strength, self-control, personality, intelligence, noble character, and the skills needed by themselves, society, nation, and state. Paragraph (2) reads; "Education based on Pancasila and the 1945 Constitution of the Republic of Indonesia is rooted in religious values, national culture and responsive to the demands of changing times. In this case, religion is an educational goal (so that students have spiritual strength) and a source of value in the national education process.

In Article 4 paragraph (1), the same Law reads; "Education is held democratically and fairly and is not discriminatory by upholding human rights, religious values, cultural values, and national diversity. Article 12 paragraph (1) part a reads; "Every student in every education unit has the right to get religious education following the religion he professes and is taught by educators of the same religion. Article 15 reads; "This type of education includes general, vocational, academic, professional, vocational, religious and special education. Article 17 paragraph (2) reads; "Basic education takes the form of elementary school (SD) and Madrasah Ibtidaiyah (MI) or other equivalent forms and junior high schools (SMP) and Madrasah Tsanawiyah (MTs), or other forms of equivalent.

Furthermore, Article 18 paragraph (3) reads; "Secondary education is in the form of high school (SMA), Madrasah Aliyah (MA), Vocational High School (SMK), and Vocational Madrasah Aliyah (MAK), or other forms of equivalent. Article 28 paragraph (3) reads; "Early childhood education in the form of formal education in the form of kindergarten (TK), Raudlatul Athfal (RA), or other equivalent forms. Article 30 concerning religious education reads; "Religious education is carried out by the government and/or community groups of religious adherents, following statutory regulations". In this case, religious education is the responsibility of the government and society. In addition to formal schools/madrasas established by the government such as MIN, MTsN, and MAN, the community can also organize religious education, both formal (Islamic boarding school 
and madrasa), non-formal (Al-Quran Education Park, Majlis Taklim), and informal (Madrasa Diniyah).

If we look at each of the 2003 National Education Law articles, it can be concluded that religious education has a very important position in national education. Religious education is more focused on shaping students to actively develop their potential to have religious-spiritual power and piety to God Almighty.

However, the above situation is not a guarantee that the reality of Islamic education in Indonesia runs well. Religious education is underestimated by the public. This can be seen when the interest of the community to send their children to religious education institutions such as madrasas and Islamic Boarding Schools is still low. Religious education institutions become the second priority after public schools. One reason is the quality of religious education institutions are lower than public schools. Even though several Islamic educational institutions can compete by displaying each other's uniqueness in attracting the sympathy of the community.

The journey of Indonesia's education policy has not ended, in 2004 the government established a Competency-Based Curriculum (CBC). The presence of the $\mathrm{CBC}$ initially fosters hope that it will benefit students because it is considered a refinement of the Active Student Learning Method (CBSA) method. But in terms of mental and teacher capacity seems very heavy to meet these demands. The government was also very conceptually overwhelmed when the government insisted on the implementation of the National Examination so that the KBK was replaced and perfected with the Education Unit Level Curriculum (KTSP). And currently, the government is preparing the latest curriculum, which is a continuation of the 2004 CompetencyBased Curriculum (CBC).

\section{CONCLUSION}

During the Old Order era, Islamic boarding schools and madrasas experienced discrimination when compared to public schools. Government recognition of the existence of Islamic boarding schools and madrasas began to appear during the New Order era, especially in the last two decades of the 1980s to 1990s. The New Order policy that did not separate religious education from the national education system was reflected in: first, madrasas are autonomous educational 
institutions under the supervision of the Minister of Religion. The autonomy of is carried out by formalizing and structuring madrasas. Second, the issuance of a policy in the form of a Joint Ministerial Decree in 1974 in improving the quality of education in madrasas. Third, the birth of Law No.2 of 1989 concerning the National Education System.

During the Reformation period, the existence of madrasas as Isla $\mathrm{m}$ ic educational institutions was increasingly recognized by the government with the enactment of Law Number 20 of 2003 concerning the National Education System, which was marked by the strengthening of the Islamic education system as a national educational institution. Islamic educational institutions during the Reformation era had a greater opportunity to grow and develop and increase their contribution to the development of national education.

\section{REFERENCES}

Amin, Samsul Munir. Sejarah Peradaban Islam. Jakarta: Amzah, 2010.

Anwar, Ali. Pembaruan Pendidikan di Islamic Boarding School Lirboyo Kediri. Yogyakarta: Pustaka Pelajar, 2010.

Azra , Azyumardi. Paradigma Baru Pendidikan Nasional: Rekonstruksi dan Demokratisasi. Jakarta: Kompas, 2002.

Bruinessen, Martin van. NU: Tradisi, Relasi-relasi Kuasa, Pencarian Wacana Baru, Terj. Farid Wajidi. Yogyakarta: LKIS, 1994.

Choi r i, Moh. Miftachul, and Aries Fitriani. "Problematika Pend i dikan Islam Sebagai Sub Sistem Pendidikan Nasional di Era Global." Al-Tahrir: Jurnal Pemikiran Islam 11, no. 2 (2011).

Daulay, Haidar Putra. Pendidikan Islam dalam Sistem Pendidikan Nasional Indonesia. Jakarta: Kencana Prenada Media Group, 2004.

Dunn, William N. Pengantar Analisis Kebijakan Publik. Yogyakarta: Gajah Mada University Press, 1999. 
Hadi, Hasbullah, Didin Hafidhuddin, Adian Husaini, and Endin Muja h idin. "Kebijakan Pendidikan Nasional Terhadap Pend idikan Islam dan Pendidikan Sekuler." Miqot XL, no. 2 (2016).

Indo n esia, Undang-undang Republik. Nomor 20 Tahun 2003 Tentang Sistem Pendidikan Nasional (2003).

Kansil, C.S.T. Mendalami P4, UUD 1945, dan GBHN. Jakarta: PN Balai Pustaka, 1985.

Latief, Djamil. Himpunan Peraturan-peraturan Tentang Pendidikan Agama. Jakarta: Ditbinpendais Depag RI, 1983.

Madjid, Nurcholish. Bilik-bilik Islamic Boarding School: Sebuah Potret Perjalanan. Jakarta: Dian Rakyat, 1997.

Maksum. Madrash; Sejarah dan Perkembangannya. Jakarta: Logos Wacana Ilmu, 1999.

Qoma r, Mujamil. Islamic Boarding School: Dari Transformasi Metodologi Menuju Demokratisasi Institusi. Jakarta: Erlangga, 1996.

Rokim. “Analisis Kebijakan Versi Dunn \& Implementasinya dalam Pendidikan Islam.” Pancawahana 14, no. 2 (2019).

Sale h, Abdurahman. Penyelenggaraan Madrasah: Peraturan Perundangan. Jakarta: Dharma Bhakti, 1984.

Sari d jo, Marwan. Sejarah Pondok Islamic Boarding School di Indonesia. Jakarta: Dharma Bhakti, 1982.

SKI Fakultas Adab UIN Yogyakarta. Sejarah Peradaban Islam di Indonesia. Yogyakarta: Pustaka, 2006.

Steenbrink, Karel A. Islamic Boarding School, Madrasah, Sekolah: Pendidikan Islam dalam Kurun Modern. Jakarta: LP3S, 1994.

Sumardi, Mulyanto. Sejarah Singkat Pendidikan Islam di Indonesia 1945-1975. Jakarta: Dharma Bhakti, 1978.

Tadjab. "Posisi Pendidikan Islam dalam Sistem Pendidikan Nasional.” Fakultas Pasca Sarjana IAIN Sunan Kalijaga, 1987. 
Tilaar, H.A.R. Paradigma Baru Pendidikan Nasional. Bandung: Rineka Cipta, 2004.

Yati m, Badri. Sejarah Peradaban Islam: Dirasah Islamiyah II. Jakarta: Rajawali Pers, 2010. 